\title{
Development of gluten-free cookie from medicinal plants (Guaraná - Paullinea cupana and Catuaba - Anemopaegma mirandum) aiming at copper, iron, and zinc supplementation
}

\author{
Elaboração de biscoito sem glúten a base de ervas medicinais (Guaraná - Paullinea cupana e \\ Catuaba - Anemopaegma mirandum) visando suplementação de cobre, ferro e zinco
}

Karina Emerick de OLIVEIRA ${ }^{1}$, Iracema TAKASE², Édira Castello Branco de Andrade GONÇALVES ${ }^{1 *}$

\begin{abstract}
Two flavors of cookies were developed (savory and peppery) containing a mixture of plants such as "guaraná" (Paullinia cupana) and "catuaba" (Anemopaegma mirandum). A test of acceptance and buying intention was applied to 48 consumers through a structured hedonic scale of 9 points. Afterwards, the centesimal compositions of these cookies were obtained as well as their total contents of copper, iron, and zinc through the method of atomic absorption spectrometry with flame. Sensorial tests indicated that the cookies presented good acceptance with potential to sensorial growth. The amount of fibers in the samples, $3 \mathrm{~g} / 100 \mathrm{~g}$, surpassed expectations since the product was not invented with the intention of being a source of this nutrient. The total amount of copper $\left(0.41 \mathrm{mg} .100 \mathrm{~g}^{-1}\right)$, iron $\left(4.50 \mathrm{mg} .100 \mathrm{~g}^{-1}\right)$, and zinc $\left(1.32 \mathrm{mg} .100 \mathrm{~g}^{-1}\right)$ was considered good. The cookies produced can be considered good sources of fibers, copper, iron, and zinc. Furthermore, they are beneficial to people affected by celiac disease because they lack gluten. They also present functional properties. In addition, the medicinal plants used are considered energetic.

Keywords: medicinal plants; copper; iron; zinc; gluten.
\end{abstract}

\section{Resumo}

Foram elaborados dois biscoitos (salgado e apimentado) à base de guaraná e catuaba. Testes de aceitação e de intenção de compra foram aplicados em 48 consumidores. Determinou-se a composição centesimal dos produtos elaborados bem como os teores totais de cobre, ferro e zinco através da espectrometria de absorção atômica em chama. Os testes sensoriais indicaram que os biscoitos apresentam boa aceitação com potencial de crescimento sensorial. O teor de fibras encontrado nos biscoitos, $3 \mathrm{~g} / 100 \mathrm{~g}$, ultrapassou as expectativas, pois não foram inicialmente elaborados com esta finalidade. Os teores totais de cobre $\left(0,41 \mathrm{mg} \cdot 100 \mathrm{~g}^{-1}\right)$, ferro $\left(4,50 \mathrm{mg} \cdot 100 \mathrm{~g}^{-1}\right)$ e zinco $\left(1,32 \mathrm{mg} .100 \mathrm{~g}{ }^{-1}\right)$ permitem que o produto possa ser considerado fonte destes minerais. O produto obtido, além de ter a ação "energética" das plantas medicinais utilizadas, pode ser considerado como fonte de fibras, cobre, ferro e zinco e também mais uma alternativa para o grupo de celíacos.

Palavras-chave: ervas medicinais; cobre; ferro; zinco; glúten.

\section{Introduction}

Minerals form a group of elements widely distributed in nature and that fulfill diverse functions in the human body. A total of $99 \mathrm{~g} / 100 \mathrm{~g}$ of which is made up of macronutrients (molecules that contain $\mathrm{C}, \mathrm{H}, \mathrm{O}$, and $\mathrm{N}$ represented by water, carbohydrates, lipids, and proteins). Around $1 \mathrm{~g} / 100 \mathrm{~g}$ of an adult man's body corresponds to micronutrients and among them are trace elements, which represent less than $0.01 \mathrm{~g} / 100 \mathrm{~g}$ of body composition. Trace elements considered essentials, such as copper, iron, and zinc play important roles related to enzymatic catalysis and or maintenance of molecules integrity (COZZOLINO, 2005; MAHAN; KRAUSE, 2005).

Among all the minerals known, copper, iron, and zinc can be highlighted, being classified as essential microelements or trace elements, playing essential roles in human body function (LEHNINGER,1998; OMS, 1998).

Celiac disease is characterized as a permanent intolerance to gluten. This usually appears during childhood between the first and third year of life. However, this could develop at any age, which includes adult life. Its treatment consists of a gluten-free diet, in which people affected by this disease cannot consume food like bread, cakes, biscuit, pasta, salty cookies made of wheat, pizza, beer, whisky, vodka, and etc. due to the content of gluten they present or which is added during their production (MORISHITA et al. 2003; SDEPANIAN et al. 1999).

Gluten is the main protein present in wheat, oat, rye, barley, and malt (a sub product from barley), cereals widely

Recebido para publicação em 13/12/2007

Aceito para publicação em 3/1/2009 (003095)

Departamento de Tecnologia dos Alimentos, Escola de Nutrição, Universidade Federal do Estado do Rio de Janeiro - UNIRIO, Av. Pasteur, 296, Urca, CEP 22290-240,

E-mail: ediracba@analisedealimentos.com.br

${ }^{2}$ Instituto de Química, Universidade Federal do Rio de Janeiro - UFRJ

${ }^{*}$ A quem a correspondência deve ser enviada 
used in food production. It contains 2 fractions of protein: gliadin and glutenin. Gliadin presents a molecular weight of 40.000 on average, a simple chain, and it is extremely gummy when hydrated showing none or little resistance to extension, and therefore, it is responsible for mass cohesion. Glutenin is formed by various chains joined presenting a mean molecular weight that ranges from 100.000 to thousands. It is elastic but not cohesive, and it does not provide resistance to extension. Some authors state that no other cereal presents proteins capable of forming dough like wheat does (TEDRUS et al. 2001).

What is harmful and toxic to the patient intolerant to gluten are the called "gluten parts", which are named accordingly to each cereal. In wheat, it is called gliadin, in barley is hordein, in oat is avenin, and in rye is secalin. Malt, which is highly questioned, is a product of barley's fermentation. Thus, it also represents a fraction of gluten, so those products in which gluten is present should not be consumed by people with celiac disease. Gluten does not disappear when foods are baked or cooked. Thus, the diet should be strictly followed. Gluten damages small bowels' microvilosities impairing nutrient absorption (MORISHITA et al., 2003; SDEPANIAN et al., 1999).

Rice flour is obtained through grounded rice (Oryza Sativa) grains. Its chemical composition makes this a product of good digestibility when compared to other types of cereals. Starch is present in around 80/100 $\mathrm{g}$ of the product (being 27/100 $\mathrm{g}$ as amilose and 57/100 $\mathrm{g}$ as amilopectin). The proteins orizin and orizein, from rice, are suitable to celiac patients. As for the rheologic aspects, rice flour exhibits 55/100 g of its protein fraction as glutenin and 25/100 $\mathrm{g}$ as prolamin allowing, together with starch content, a good capacity of water retention, viscosity, and mass elasticity (TEDRUS et al., 2001).

Medicinal plants, plants that contain bioactive compounds with therapeutic, prophylactic, or palliative properties, have been widely studied and commercialized worldwide. The majority of these studies focus on its active principle, normally organic compounds with diverse functions in the body. Given that their consume is increasing, it is interesting to use these plants as a supplement in food taking into account that these plants can present a significant amount of copper, iron, and zinc (ALVES, 2000; CORREA, 1984; ANDRADE; ALVES; TAKASE, 2005a, b).

Guaraná powder is derived from the seed of Paullinia cupana after being dried and then ground or smashed. Its chemical composition is rich in compounds derived from xantin like teofilin, teobromin, and caffeine, and it has been considered the most potent source of metilxantins stimulating the central nervous system (CNS) (ARAÚJO et al., 2006; TFOUNI et al., 2007).

Catuaba (Anemopaegma mirandum) is constituted by alkaloids, similar to atropine, which concentrate in the rind and act upon nervous centers interfering in the conduction of motor nervous impulse through depressive or excitatory mechanisms (KLETTER et al., 2004).

Considering the increase in the frequency of consumption of these plants, it is believed that their use as mineral supplements is interesting. Therefore, the objective of the present work was to develop a cookie made up of guaraná and catuaba lacking gluten.

\section{Materials and methods}

\subsection{Samples}

Two flavors of cookies were developed (savory and peppery) containing a mixture of plants such as "guaraná" (Paullinia cupana) and "catuaba" (Anemopaegma mirandum). Rice flour was also used in place of wheat flour, and olive oil, orange juice, and some condiments were added to give different flavors. All the cookies were baked in a pre-warmed oven around $180^{\circ} \mathrm{C}$. The basic formulation used was obtained through preliminary tests described in Table 1 taking using the methodology proposed by AACC (1995) as reference, method number 10-50D. The fluxogram of production is presented in Figure 1.

\subsection{Sensorial analysis and buying intention}

This study is part of the project "Development of bread products with medicinal herbs, fruits, and flours aiming at fibers, iron, cupper, and zinc supplementation. It was approved by the Committee of Ethics in Research of the Federal University of the State of Rio de Janeiro (CEP-UNIRIO) with protocol CAAE No 0009.0.313.000-08.

In order to analyze the acceptance and buying intention, 2 samples of the cookie (savory and peppery) were evaluated by 48 consumers of this kind of product using a structured hedonic scale of 9 points. Buyers received a form as follows:

Name: Age: Sex:

You are receiving 2 samples of cookies made up of "guaraná" and "catuaba". These products are aimed to act as mineral and energetic supplement. Please, try each one as explained drinking water between each sample and mark in the scale how much you liked the product.

I agree to take part in this study of acceptance of medicinal plant cookies, and authorize the use of the data showed bellow.

Rio de Janeiro, 2006.

Month/day Signature

\subsection{Cookie A}

disliked disliked disliked don't like don't like liked liked Liked a lot liked

extremely a lot moderately slightly nor dislike slightly moderately extremely

Would you buy this product?

Certainly May buy certainly

Wouldn't buy May not buy would buy 
Table 1. Formulation of "guaraná" and "catuaba" cookies with different concentrations of rice flour.

\begin{tabular}{|c|c|c|c|}
\hline Ingredients & $\begin{array}{l}\text { Wheat flour/rice flour } \\
100 \mathrm{~g} / 0 \mathrm{~g}\end{array}$ & $\begin{array}{l}\text { Wheat flour/rice flour } \\
50 \mathrm{~g} / 50 \mathrm{~g}\end{array}$ & $\begin{array}{l}\text { Wheat flour/rice flour } \\
0 \mathrm{~g} / 100 \mathrm{~g}\end{array}$ \\
\hline Wheat flour & $50,0 \mathrm{~g} / 100 \mathrm{~g}$ & $25,0 \mathrm{~g} / 100 \mathrm{~g}$ & - \\
\hline Rice flour & - & $25,0 \mathrm{~g} / 100 \mathrm{~g}$ & $41,0 \mathrm{~g} / 100 \mathrm{~g}$ \\
\hline Leaven & $1,0 \mathrm{~g} / 100 \mathrm{~g}$ & $1,0 \mathrm{~g} / 100 \mathrm{~g}$ & $1,0 \mathrm{~g} / 100 \mathrm{~g}$ \\
\hline Salt & $2,5 \mathrm{~g} / 100 \mathrm{~g}$ & $3,0 \mathrm{~g} / 100 \mathrm{~g}$ & $2,0 \mathrm{~g} / 100 \mathrm{~g}$ \\
\hline "Guaraná" & $4,0 \mathrm{~g} / 100 \mathrm{~g}$ & $4,0 \mathrm{~g} / 100 \mathrm{~g}$ & $6,0 \mathrm{~g} / 100 \mathrm{~g}$ \\
\hline "Catuaba" & $4,0 \mathrm{~g} / 100 \mathrm{~g}$ & $4,0 \mathrm{~g} / 100 \mathrm{~g}$ & $6,0 \mathrm{~g} / 100 \mathrm{~g}$ \\
\hline Coffee & - & - & $1,0 \mathrm{~g} / 100 \mathrm{~g}$ \\
\hline Olive oil & $16,5 \mathrm{~g} / 100 \mathrm{~g}$ & $16,5 \mathrm{~g} / 100 \mathrm{~g}$ & $28,0 \mathrm{~g} / 100 \mathrm{~g}$ \\
\hline Orange & $21,0 \mathrm{~g} / 100 \mathrm{~g}$ & $21 \mathrm{~g} / 100 \mathrm{~g}$ & $11,0 \mathrm{~g} / 100 \mathrm{~g}$ \\
\hline Condiments and aromatic plants & $1,0 \mathrm{~g} / 100 \mathrm{~g}$ & $0,5 \mathrm{~g} / 100 \mathrm{~g}$ & $4,0 \mathrm{~g} / 100 \mathrm{~g}$ \\
\hline
\end{tabular}

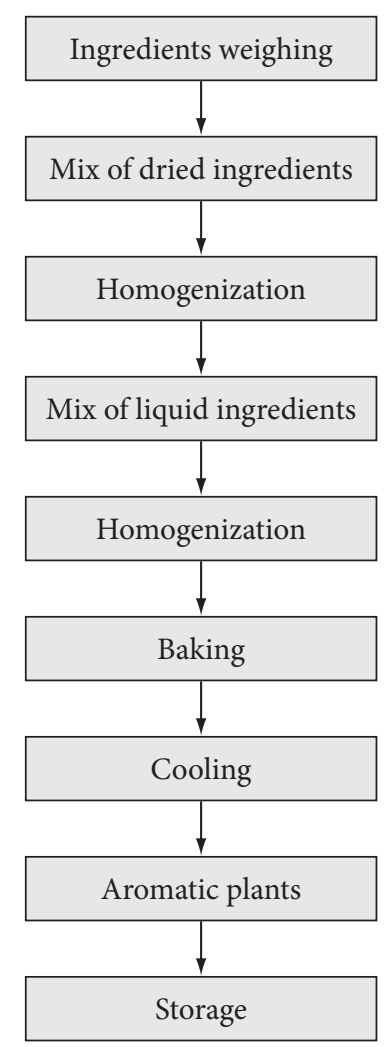

Figure 1. Fluxogram of the production of gluten-free cookies made up of "guaraná" and Catuaba".

What did you like most in this product?

What did you dislike most in this product?

The samples were presented at random, in a monadic way, according to the codes in the acceptance form, in white napkins, codified with 3 numbers and served at room temperature.

\subsection{Determination of chemical composition}

Water, mineral, protein, lipid, fiber and carbohydrate contents were determined according to AOAC analytic methods (AOAC, 1997).

\subsection{Determination of total content of copper, iron and zinc}

The total contents of copper, iron, and zinc were determined through the method of atomic absorption spectrometry with flame. Samples were analyzed in quadruplicate (AOAC, 1997).

\subsection{Statistical analysis}

Data concerning acceptability and buying intention were subjected to analysis of variance $($ ANOVA $)(p<0.05)$ followed by post hoc test of Tukey. In order to analyze the rejection of remaining results, the Dixon's $\mathrm{Q}$ test was used.

\section{Results and discussion}

Analyzing the means in Table 2, it can be said after the savoury cookie samples were preferred when compared to the peppery ones. Even though the savory cookie presented higher mean values, they were not different from the peppery means $(p<0.05)$. Moreover, it is noteworthy to say that the means fall within the options "slightly disliked", "don't like, nor dislike", and "slightly liked" indicating that the product shows potential to sensorial growth.

Using the same analysis to evaluate buying intention, it was observed that the results were similar to the acceptance test, in which the savory cookie was preferred in numeric terms, but with no statistical difference when compared to the peppery cookie $(\mathrm{p} \leq 0.05)$.

Figure 2 illustrates the performance of each sample when it comes to preference through the individual answer of consumers. Thus, it can be noted that for both samples the majority of consumers are located in the positive side of the scale. At about $42 \mathrm{~g} / 100 \mathrm{~g}$ of the consumers showed acceptance by choosing the terms "moderately liked", "liked a lot", and "extremely liked", which confirm the potential of the products to this sort of consumers. On the other hand, the peppery samples presented only $27 \mathrm{~g} / 100 \mathrm{~g}$ of consumers expressing acceptance in this same part of the scale indicating less potential of acceptance. 
Table 2. Mean ${ }^{\star}$ of acceptance ${ }^{\star *}$ and buying intention ${ }^{* \star}$ attributed to the samples of cookies.

\begin{tabular}{lcc}
\hline Sample & Acceptance & Buying intention \\
\cline { 2 - 3 } & $\mathrm{MSD}^{* * * *}=0,87$ & MSD $^{* * * *}=0,86$ \\
\hline Savory & $5.60^{\mathrm{a}}$ & $4.19^{\mathrm{b}}$ \\
Peppery & $4.75^{\mathrm{a}}$ & $3.48^{\mathrm{b}}$ \\
\hline
\end{tabular}

${ }^{\star}$ Means with equal letters in the same column are not different after Tukey test ( $\left.\mathrm{p} \leq 0.05\right)$; ${ }^{* *} 1=$ extremely disliked until $9=$ extremely liked; ${ }^{* * *} 1=$ probably wouldn't buy until

7 = probably would buy; and ${ }^{* * * *} \mathrm{MSD}=$ Minimal significant difference.

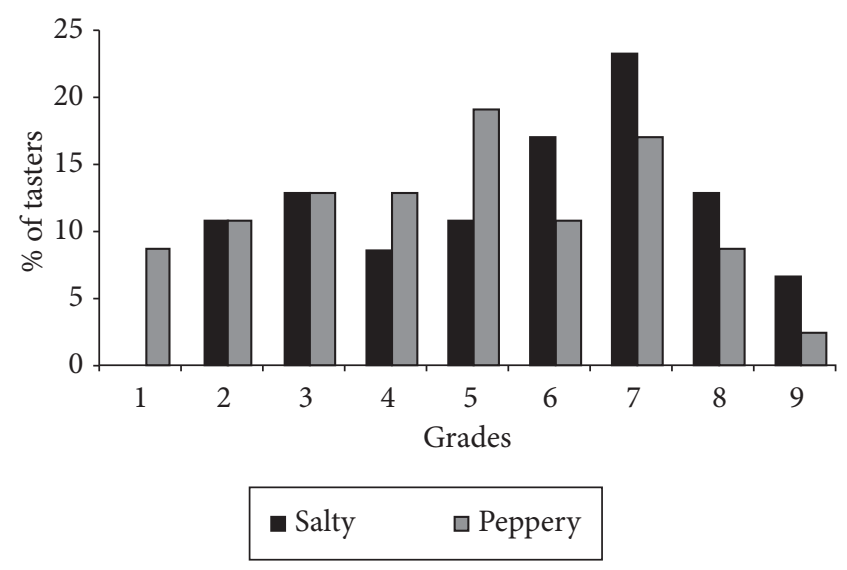

Figure 2. Histogram $\mathrm{f}$ distribuition of grades given by the tasters.

It is important to highlight that according to Deliza and Macfie (1996) and Deliza and Costa (2003), the choice and consequent buying of a food by the consumer is influenced by many inter-related factors and not only by the intrinsic characteristics of the product. These factors range from previous experiences with the product to the context, available information, and consumer's personality.

As for the Chemical composition of the product, Table 3 shows that the carbohydrate fraction was the most representative corresponding to almost $70 \mathrm{~g} / 100 \mathrm{~g}$ of the whole composition of the cookies. Rice flour was the ingredient responsible for this fraction almost entirely since it contains more than $80 \mathrm{~g} / 100 \mathrm{~g}$ of starch.

Such starch is basically formed by amilose and amilopectin. The former is a linear polymer, and for that reason it presents high resistance against the breakup of the chain. This characteristic suggests that foods rich in amilose display smaller elasticity and capacity to retain water. Conversely, amilopectin is more likely to retain water and form gel when heated because of its ramifications. Therefore, starches rich in amilopectin are more elastic and suitable to the fabrication of breads and pastas (TEDRUS et al., 2001).

The possibility of using rice flour in the productions of bakery goods increase the value attached to this raw material, which is considered a sub-product of the production of rice since the broken grains have got little industrial application (TEDRUS et al., 2001).
Table 3. Chemical compositionof cookies in $\mathrm{g} / 100 \mathrm{~g}(\mathrm{~N}=4)$.

\begin{tabular}{lcc}
\hline \multicolumn{1}{c}{ Analysis } & Salty cookie & Peppery cookie \\
\hline Humidity & $2.68 \pm 0.16$ & $2.65 \pm 0.09$ \\
Mineral & $6.62 \pm 0.20$ & $6.48 \pm 0.14$ \\
Fiber & $3.18 \pm 0.19$ & $3.03 \pm 0.33$ \\
Protein & $5.4 \pm 0.10$ & $5.4 \pm 0.18$ \\
Lipid & $14.06 \pm 1.23$ & $14.43 \pm 0.87$ \\
Carbohydrates & 68.06 & 68.01 \\
\hline
\end{tabular}

Table 4. Total content of copper, iron, and zinc (mg.100 g $\left.\mathrm{g}^{-1}\right)$ and $/ 100 \mathrm{~g}$ $\mathrm{RDA}^{\star}$ for $100 \mathrm{~g}$ of samples of cookies $(\mathrm{N}=4)$

\begin{tabular}{lccc}
\hline \multicolumn{1}{c}{ Samples } & Ferro & Cobre & Zinco \\
\hline Savory cookie & $4.50 \pm 0.34$ & $0.41 \pm 0.03$ & $1.32 \pm 0.09$ \\
Peppery cookie & $4.78 \pm 0.51$ & $0.44 \pm 0.08$ & $1.31 \pm 0.12$ \\
$/ 100$ g RDA $^{*}$ & 45.60 & 45.00 & 8.80 \\
\hline
\end{tabular}

${ }^{*} \mathrm{RDA} / 1989$ - adult men.

The amount of fibers in the samples, $3 \mathrm{~g} / 100 \mathrm{~g}$, surpassed the expectations since the product was not developed with the intention of being a source of this nutrient. Cookies made with different levels of substitution of wheat flour for apple fiber aiming at the supplementation of this nutrient present total fiber value ranging from 2.70 to $6.05 \mathrm{~g} / 100 \mathrm{~g}$. Likewise, cookies developed with $10 \mathrm{~g} / 100 \mathrm{~g}$ of jatobá-do-cerrado and jatobáda-mata show values of 5.44 and $6.25 \mathrm{~g} / 100 \mathrm{~g}$, respectively (SILVA et al., 2001).

Observing the data shown in Table 4, it is possible to note that there was no significant difference between the different flavors in relation to iron, copper, and zinc contents.

The amount of iron found in $100 \mathrm{~g}$ of the cookie is considered high when compared with other products considered source of this mineral such as molasses $\left(7.40 \mathrm{mg} .100 \mathrm{~g}^{-1}\right)$, black beans ( $\left.4.30 \mathrm{mg} .100 \mathrm{~g} \mathrm{~g}^{-1}\right)$, and cooked red meat $\left(3.8 \mathrm{mg} .100 \mathrm{~g} \mathrm{~g}^{-1}\right)$. A portion of $30 \mathrm{~g}$ of the savory cookie, amount usually used as cookies' portion, provides around $17 \%$ of iron's recommendation (MAHAN; KRAUSE, 2005).

Andrade et al. (2003), evaluated the mean content of copper found in food, in which leguminous were considered sources of copper with an average of $0.90 \mathrm{mg} \cdot 100 \mathrm{~g}^{-1}$. Based on these results, it is possible to state that the cookies analyzed present representative values of this mineral reaching up to $13.7 \%$ of $\mathrm{RDA}(0.9 \mathrm{mg}$ to adult individuals, both genders) with only $30 \mathrm{~g}$ of the savory sample.

The same study described above was carried out for zinc, in which the best sources were red meat $\left(3 \mathrm{mg} \cdot 100 \mathrm{~g}^{-1}\right)$ and leguminous $\left(3 \mathrm{mg} .100 \mathrm{~g}^{-1}\right)$. As a result, the studied cookies present significant contents of this micronutrient reaching around $3.6 \%$ of RDA ( $11 \mathrm{mg}$ for adult men) with a $30 \mathrm{~g}$ portion (ANDRADE et al., 2003). 


\section{Conclusions}

The cookies developed in this study presented good acceptance among consumers and possibilities of sensorial growth as well. They present satisfactory amounts of copper, iron, and zinc acting as important assistants in the supplementation of each of these minerals. Furthermore, they can be considered sources of fibers and important options to substitute bakery goods for celiac patients.

\section{References}

ALVES, T. M. et al. Biological screening of brazilian medicinal plants. Memórias do Instituto Oswaldo Cruz, v. 95, n. 3, p. 367-373, 2000.

American Association of Cereal Chemists - AACC. Appoved methods. 9 ed. Saint Paul: AACC, 1995.

ANDRADE, E. C. B.; BARROS, A. M.; TAKASE, I. Copper and zinc in foods. Revista Higiene Alimentar, v. 17, n. 107, p. 103-106, 2003.

ANDRADE, E. C. B.; ALVES, S. P.; TAKASE, I. Evaluation of the use of medicinal grass as nutritional s0upplement of iron, copper and zinc. Ciência e Tecnologia de Alimentos, v. 25, n. 3, p. 591-596, 2005a.

ANDRADE, E. C. B.; ALVES, S. P.; TAKASE, I. Sequential extraction of copper, iron and zinc in medicinal plants. Ciência e Tecnologia de Alimentos, v. 25, n. 4, p. 844-848, 2005b.

ARAÚJO, A. A. S. et al. Determination of humidity and ash content of guarana commercial samples using conventional method and thermal analysis. Revista Brasileira de Ciências Farmacêuticas, v. 42, n. 2, p. 269-277, 2006.

Association of Official Analytical Chemists International - AOAC. Official Methods of Analysis. 16 ed. Gaitherburg, 1997.

CORREAA, M. P. Dicionário das plantas úteis do Brasil e das exóticas cultivadas. Rio de Janeiro: Instituto Brasileiro de Desenvolvimento Florestal, 1984.
COZZOLINO, S. M. F. Biodisponibilidade de nutrientes. São Paulo: Manole, 2005.

DELIZA, R.; MACFIE, H. J. H. The generation of expectation by external cues and its effects on sensory perception and hedonic ratings: a review. Journal of Sensory Studies, v. 11, p.103-128, 1996.

DELIZA, R.; ROSENTHAL, A.; COSTA, M. C. Translation and validation into portuguese language of scale used in consumer studies. Ciência e Tecnologia de Alimentos, v. 23, n. 1, p. 43-48, 2003.

KLETTER, C. et al. Morphological, chemical and functional analysis of catuaba preparations. Planta Medica, v. 70, n. 10, p. 993-1000, 2004.

LEHNINGER A. L.; NELSON, D. L.; COX, M. M. Princípios de Bioquímica. 2 ed. São Paulo: Editora Sarvier, 1998.

MAHAN L. K.; ESCOTE-STUMP, S. Krause: Alimentos, Nutrição e Dietoterapia. 11 ed. São Paulo: Editora Roca, 2005.

MORISHITA, T.; KAMIYA, T.; ISHII, H. Magnifying endoscopy of the duodenum with dye scattering method in a case with celiac disease. Arquivos de Gastroenterologia, v. 40, n. 2, p. 110-113, 2003.

Organização Mundial de Saúde - OMS. Elementos traço na nutrição e saúde humanas. 1 ed. São Paulo: Editora Roca, 1998.

SILVA, M. R. et al. Studies on the use of jatoba flour in biscuits as a source of dietary fibre containing no added simple sugars. Revista Ciência e Tecnologia de Alimentos, v. 21, n. 2, p. 176-182, 2001.

SDEPANIAN, V. L.; MORAIS, M. B.; FAGUNDES-NETO, U. Celiac disease: evolution in knowledge since its original centennial description up to the present days. Arquivos de Gastroenterologia, v. 36, n. 4, p. 244-257, 1999.

TEDRUS, G. et al. Effects of the addition of vital gluten to rice flour, oat flour and wheat starch on the quality of breads. Ciência e Tecnologia de Alimentos, v. 21, n. 1, p. 20-25, 2001.

TFOUNI, S. A. V. et al. Contribution of guaraná powder (Paullinia cupana) as a source of caffeine in the diet. Revista de Nutrição, v. 20 , n. 1, p. $63-68,2007$. 